\title{
Agrarian Politic and Food Security in the Islamic Economic System
}

\author{
Hady Sutjipto ${ }^{1}$, Lina Affifatusholihah ${ }^{2}$ \\ \{hadysutjipto@untirta.ac.id ${ }^{1}$, lina@untirta.ac.id $\left.{ }^{2}\right\}$ \\ ${ }^{1,2}$ Department of Economic, University of Sultan Ageng Tirtayasa, Indonesia
}

\begin{abstract}
This research aims to analyze agrarian policies and food securities in the Islamic Economic system. The method used in this research is a qualitative descriptive that describes critically agrarian policies in the Islamic Economic system. This study uses secondary data derived from books, literatures, scientific articles and other information related to agrarian policy. The results of the study indicate that Islamic economic politics of agrarian is the best policy as an alternative policy to overcome agrarian problems and food securities. Agrarian political facts show that the management of agricultural land is still largely in the form of land rent of unproductive and abandoned agricultural and this endangers food security. As a result, farmers continue to suffer losses and the occurrence of food dependence from abroad. This research suggests that the government in reforming the Agrarian Law implement agrarian politics in the Islamic economy to achieve sustainable food security.
\end{abstract}

Keywords: Agrarian Politics, Food Security, Islamic Economy

\section{Introduction}

Starting from the policy that concerning "Provisions Regarding Land Acquisition Procedures ", which is made an easy for investors to acquire land, then began the era where land became a commodity with various facilities for investors to obtain it. In general, this policy led to three things, the increasing vulnerability of community's agrarian property to investors in various business fields, the rise of land disputes vertically and horizontally, as well as the development of land tenure for speculation [1]. Therefore, in the economic conversation, agrarian problems have always been a problem that seems never ending until nowadays.

Land is the most important factor of production which is the most serious study of economists, because of its superior nature which is not possessed by other factors of production. Land characteristics are land can fulfill basic and permanent human needs, limited quantity of land and land is fixed. Another characteristic is that land is not a product of labor. The whole thing else is a product of labor except land. Within the community, land issues have also been a cause of disagreement, conflict and bloodshed between communities. Land also subsidizes greatly to changes in the organization and structure of society [2]

Development of the basic agrarian law raises five issues namely, social function of land, maximum land ownership, stalled land ownership, Monopolization of land ownership, and determination of land compensation. These five things often trigger the emergence of various agrarian conflicts that are not easy to resolve [3] 
The most noticeable fact in the agrarian problem is the occurrence of injustice or discrepancy in land tenure. The economic system of capitalism and socialism, in this case, is more or less produced due to social distrust of people who own land due to special rights and make it a tool of public exploitation.

Land proprietorship is considered to be the most special type of ownership in capitalist countries. Land may be owned by individuals as widely as possible, even leasing it out to the public at a subjective rent and sale price. As a result, prices of staples rise and inflation occurs. For the state, land becomes fruitful ground for taxation. The Henry George's movement on a single tax (1886) had millions of factions in the United States. Based on such proofs, he reasoned that in principle of land tenure would provide an added value and therefore could be subject to high taxes without the need an adjustment of production incentives.

On the other hand, individual land ownership is not recognized in socialist societies. Farmers and workers are prohibited from taking added value from their work. Their status is solely as farm laborers. This system factually led to economic imbalances and made socialist countries be unsuccessful to achieve food self-sufficiency in the mid-twentieth century. They still depended on other countries to meet their food needs [4] .

Land requirements for various sectors are increasing along with the increasing population, and the rapid economic development, especially around urban areas and around industrial centers. Transfer of land functions has serious implications for food production, physical environment, and community welfare. The conversion of the function of productive agricultural land has been considered to be less balanced by integrated efforts to develop new agricultural land through the opening of potential agricultural land [5].

Therefore, if we want to make all agrarians in a country can continue to increase their productivity in achieving sustainable food security, the right strategies or policies are needed to make it happen. At the same time, how can agrarian regulator be distributed fairly and equally for all the people to be created?

The main problem is: what strategies or policies can play a role in realizing these expectations? Until now the question of agrarian policy remains unanswered by capitalist and socialist economies. The question is, is the existing economic system capable to resolve all of these land problems completely and fairly for all humanity on this earth?

\section{Research Problem}

Based on the background above, the formulation of the problem in this study is as follows:

1. What is the agrarian political construction win the Islamic economic approach?

2. How is the agrarian political construction to achieve sustainable food security with an Islamic economic approach?

\section{Discussion}

The agricultural segment is the sector that obtains the least attention from the government in the earlier. The debate on agriculture is generally conceded without being linked to other sectors. Subsequently, economic development is seen as a dispersed part of development in other fields such as industry, trade and services and other economic sectors. Though constricted view is causing the expansion of agriculture in developing countries to be very distant behind the growth of agriculture and economic in developed countries [6].

Agriculture is an inseparable part of numerous other fields such as industry, trade, services, agrarian and so forth. Everything is an primary part of which is closely interrelated. 
Therefore, when Islam talks about the politics of agriculture, industrial politics, agrarian politics, labor politics, and trade politics - both domestic and foreign trade - all are discussed in a thoroughly related element. All these sectors in the Islamic perspective are directed towards realizing the achievement of economic and political objectives according to Islamic economics. The politics of Islamic economics is the application of various policies aimed at ensuring the fulfillment of all the basic needs of each individual community as a whole, accompanied by guarantees that enable each individual to meet complementary needs (secondary and tertiary) according to their abilities [7].

In order to achieve the realization of economic political goals, the Islamic agricultural policy is carried out. The politics of Islamic agriculture can be seen from the various policies that should be taken by the government in the field of agriculture, both the production sector (primary), the industrial sector (secondary) and the trade and service sector (tertiary). Therefore, when discussing the politics of Islamic agriculture, it means that it will discuss agricultural politics in the production, processing (industry), and trade and services sectors. This is because in the perspective of the Islamic economy, the agricultural sector is closely related to the industrial sector, trade, services and is also inseparable from the agrarian sector. In other words, agricultural politics according to Islam is very closely related to industrial politics, trade politics, labor politics, agrarian politics and so on [8].

Every economic system will positively have basic views on the birth of its regulations, including to regulate the procurement of agricultural land. In the view of the capitalist economic system, several important principles that will lie beneath the regulation of agricultural land tenure are [9]:

1. The essential justice in the acquisition of agricultural land is the provision of equal rights in ownership of agricultural land for all citizens.

2. Every citizen is allowed to own agricultural land no matter how extensive.

3. Every citizen is permitted to use his agricultural land, for whatever interests and production.

4. Every citizen is able to develop and increase ownership of his agricultural land.

If we observe the sights of the capitalist economic system in regulating agricultural land tenure, it appears at first view that the procedure is a fair agreement for all its citizens. Every citizen is given the same chance to own and escalating ownership of agricultural land. There are no boundaries and discrimination for every citizen as long as they have a capital to own it.

It turns out that in the course of history, it was proved that this arrangement has been disastrous for most people, specifically among the farmers. That's because the principle of independence in the mechanism of agricultural land is fulfilled, it will have the resulting effects:

1. The occurrence of boundless free competition in the proprietorship of agricultural land.

2. The disproportion in proprietorship of agricultural land tenure occurs.

3. The landlords of a huge agricultural land, will be gradually massive and continue to expand the ownership of the land.

4. Farmers who own minor land will more and more narrow their ownership of agricultural land.

5. Many farmers vanished ownership of their agricultural land and turn into agricultural laborers.

6. The climax is the manifestation of feudalism in agriculture.

\subsection{Agrarian Politics According to Islamic Economics}


Up until now the issue of ownership and control of land is still the main topic of the economy. In some feudal countries where land is largely controlled by landlords, inequality of ownership is solved by land reform. Japan, South Korea and Taiwan are the most intense countries in modern history carrying out land reform after the Second World War. Land reforms are carried out with the aim of eliminating, psychologically and materially, landlords who are the driving force behind these countries to gross war. This reform has a far-reaching impact on equalizing the distribution of income in rural areas and contributing to maintaining income differentials between cities and villages so that it becomes narrower than other countries. As a result of these reforms, the power of the feudal lords was destroyed, negating the leasing of agricultural land and limiting the ownership of arable land.

Islamic economics views land ownership have to be regulated as best because it can affects the stimulation of production. Islam firmly rejects the system of land tenure distribution evenly among all people as it becomes the land reform programmed. However, Islam also does not allow excessive land tenure beyond its ability to manage it. Therefore, the laws surrounding land in the view of Islamic economics have distinctive characteristics with differences in principles with other economics [10].

Islamic economics distinguishes that land is included in the category of individual ownership if there are no elements blocking it, such as the presence of mining materials or being controlled by the state. When this ownership is considered sharia legal, the land owner has the right to manage it or transfer inheritance, sale and purchase. As with other individual ownership, ownership of this land is certain without anyone else who can withdraw his rights. The state protects the belongings of citizens and protects it from the threat of interference from other parties.

[11] The solution of Islamic economics is the unification of agricultural land ownership with its production. The conclusion of this solution is extracted from 3 laws at once. The three laws are:

\section{Turning the Land of the Dead}

This law permits everyone to own dead, empty, and abandoned land, which does not appear to be the presence of a former fence, cultivated plants, buildings, etc., by turning the land on or fencing them as wide as he wants. This ownership right is based on several hadiths of the Messenger of Allah.

"Anyone who prospered land that is not owned by anyone, then he is entitled to the land." (HR. Ahmad)

"Anyone who has enclosed a plot of land with a fence, then that land is his property." (Narrated by Abu Daud)

"Whoever has turned on a piece of land is dead, then that land is his property." (Narrated by Abu Daud, Tirmizi, and Ahmad)

The arguments above indicate that the Islamic economy provides convenience and gratuity for each individual people to own any land in any size by animating or fencing it. The condition is that the land is an abandoned land, no one owns it yet.

2. The law prohibits abandonment of agricultural land for more than three years

Although the Islamic economy provides convenience and independence to individuals to own any land, by way of reviving or fencing it, there is a limit to this ease. The limitation is the prohibition to abandon the land for more than three years in a row. The prohibition was set based on several hadiths of the Prophet:

"Whoever has raised the dead land, he becomes the owner. And there is no right for those who fence off after abandoning their land for three years "(HR. Baihaqi) 
Yunus recounted from Muhammad bin Ishaq from Abdullah bin Abu Bakr said: "Bilal bin Al-Harith AI-Muzni came to the Prophet of Allah., then he asked for a plot of land from him. He then gave him a large area of land. "When the government was led by the Caliph Umar, he (Umar) said to him:" O Bilal, you have requested a large plot of land from the Prophet of Allah. Then he gave it to you. And the Prophet of Allah never refuse at all to be asked for, while you are not able (working on) the land in your hands. "Bilal replied:" Right. "Umar said:" Look, which of the lands you are able to work on, then own it. And which you are unable to work on, leave it to us, and we will share it with the Muslims. "Bilal said:" By Allah, I will not do at all and give what was given by the Prophet of Allah" Umar said:" By Allah, you should really work on it. "Then Umar took the land he was unable to work from Bilal, then he distributed to the Muslims.

The government as the party that controls the economic activity of its people will force agricultural landowners to manage their land optimally. The step taken by the government is to take ownership of land if the person concerned neglects it for three years. The land will then be given to those who need it and are able to manage it. Thus, land ownership is essentially not limited by a certain time. Land is still entitled to be owned by all rights attached to it as long as the party concerned manages it according to its use. Islam only limits the period of neglect for a period of three years.

Umar bin Khaththab r.a. said: "People who fence off land have no right (to the land

they have fenced in) after (leaving it) for three years ".

Yahya bin Adam revealed through the Amru bin Syu'aib sanad said: "The prophet of Allah have given some people a plot of land from Mazainah or Juhainah, then they ignored it, then there was a people reviving it. Umar said: "If the land were given from me, or from Abu Bakr, of course I would return it, but (the land) from the Messenger of Allah." He (Amru bin Syu'aib) said: "Umar said: 'Whoever is neglecting land for three years, which he does not manage, then someone else manages it, then the land is his."

This hadith firmly explains, that if the landowner is incapable to work on his land and leave it for three years, then the land will be taken by the government from its owner and given to someone else, as Umar bin Khaththab had done to Bilal AI-Muzni to the mine owned by his tribe, located next to Fara' in the Hijaz region.

Acquisition of abandoned land for a period of three years applies to all types of agricultural land whether obtained from purchases, inheritance, gifts, government gifts or reviving dead land. This is because the legal reason for withdrawing land is neglect for three years nevertheless of the type of land. Therefore for every land owner who leaves his land for three years, the land will be revoked and given to another person, regardless of the origin of the land ownership. This cannot be considered as having taken someone else's property in an illegal way. Because, sharia has made agricultural land ownership managed. All of this is so that the land is always planted and managed optimally.

Therefore, a landowner may plant his land with his tools, seeds, animals and workers. He may also employ workers to plant it. If he is unable to work on it, he will be assisted by the government. However, if the land is not planted by the owner, then the land will be given to someone else as a free gift, without any compensation, then he works on it. If the owner does not work on it and continues to controlling it, then it is left for three years. If the land is left, unmanaged, for three years, the government will take the land from its owner and give it to others. For anyone who needs maintenance costs will be given some capital from Baitul Mall, therefore the person concerned can manage it optimally. 
Through the two legal provisions above, Islamic economics requires that land ownership for individuals must be integrated with their willingness to produce it. It is not allowed to only own land, but it does not want to produce it.

From both two laws there is still a breach someone can have a large area of land, but if landowners does not want or unable to produce it. Then he will rent it to other people to work on it, so that the land will continue to produce, so he hopes that he will not lose his land ownership. Apparently there is a third legal provision.

3. The law prohibits renting out land for agriculture

A landowner absolutely prohibited to rent out his land for agriculture. They are not allowed to lease a land for agriculture with rent in the form of food or other things, which is produced by the agriculture, or whatever is produced from it, because everything is ijarah. Leasing land for agriculture is absolutely prohibited.

"The Prophet of Allah prohibit the taking of rent or portions of land "(HR. Muslim)

It is narrated, "The Prophet forbid renting out land. We asked: O Prophet of Allah, then we will rent it with seeds. He replied: 'Don't. 'Ask (friend): 'We will rent it with straw. He replied: "Don't." Ask (friend): 'We will rent it out with something that is on the rabbis. He replied: "Don't. You plant or you give the land to your brother." (HR. Imam Nasa'i)

In the trustworthy hadith it is governmentd: "That he (the Prophet) forbade taking rent and part of a land, and renting out a third or a quarter." Imam Abu Daud narrated from Rafi 'bin Khudaij, which the Messenger of Allah said: "Whoever owns the land, should plant the land, or should (be given) planted by his brother. And don't rent it out with a third, a quarter, or with equivalent food."

The above hadiths firmly indicate the prohibition of the Prophet towards leasing land. The prohibition, showing the existence of an order to leave it at the same time containing an indication that explains the existence of a strict prohibition. The alternative Islamic economy on this matter, is to employ other people to manage their land or if it is not able to at all, the land should be given to others as governmentd in the hadith

The prohibition on leasing agricultural land economically can be understood as an effort so that agricultural land can function optimally. This means that someone who is able to cultivate land must own land while anyone who is unable and unwilling to cultivate the land is not justified in controlling agricultural land.

However, the prohibition on renting out the land only applies to agricultural purposes (to be planted with certain crops, therefore the results can be harvested). While independence is not for other purposes, such as leased to livestock, fisheries, buildings, and industry, allowed. The exception is based on the hadith above is only intended for ground agriculture [12].

\subsection{Agrarian Policies and Food Securities in the Islamic Economic System}

Through implementing a solution from the Islamic economy, the integration of ownership of agricultural land and production, then the impact is expected to be two things, namely:

1. Increased agricultural production

Islam gives freedom for individuals to own any land in any size, as long as they are able to produce it. It is expected that there will be no idle land that will not be cultivated at all. Initially, agricultural land is expected to be always productive. Islam is also free to develop any agricultural commodity. This guarantees diversification and increased productivity.

2. Economic equality in agriculture

By the prohibition of abandoning and renting out agricultural land, it is expected that greed in land ownership can be more controlled. Thus, opportunities for farm laborers to own their own agricultural land are increasingly open. Farmers' skills get high appreciation. 
Because, for large landowners, if they are unable to work on it, they can pay farmers with high wages. If they do not want to give high wages, the farmers only need to wait three years to own the land that is not being tilled by working on it.

That is the picture of agrarian politics in the Islamic economy that governs the issue of control of agricultural land. A fair solution for humans, as well as a solution that can create mutual prosperity in agricultural productivity. Ultimately this policy will achieve food security sustainable [13].

\section{Conclusion}

Based on the analysis that has been made, some conclusions are obtained in this study, namely:

1. The impact of agricultural land ownership is still controlled by the landlords and agricultural land management is still a lot in the form of rent and unproductive and abandoned agricultural land causing liberty in the conversion of agricultural land and endangering food security. There is no agrarian politics that synergizes to create sustainable food security.

2. Agrarian politics in the Islamic economy provides construction in the form of the unification of ownership of agricultural land and production so that an increase in production and economic penetration in agriculture can be achieved to realize sustainable food security.

Based on the conclusions that have been outlined, then the advice that can be given to the government is:

1. The government have to immediately evaluate and restructure the agricultural land use policy.

2. The government have to conducts an investigation to implement the Islamic Economic system in its operations in reforming agrarian laws.

3. The government must abolish the agricultural land rent system, because this is opposing to the Islamic economy, and must return the land management system of agricultural land by the landowners.

4. The government must implement agricultural land policy with the integration of agricultural land ownership and production, therefore the agricultural production can be increased and economic equality in agriculture can be realized.

\section{References}

[1] Jamall, E. (2000) 'Beberapa Permasalahan dalam Pelaksanaan Reformasi Agraria di Indonesia', 18(1), pp. 16-24.

[2] Aju, I. et al. (2019) 'Forest Policy and Economics Indonesia' s land reform: Implications for local livelihoods and climate', Forest Policy and Economics. Elsevier, (April), p. 101903. doi: 10.1016/j.forpol.2019.04.007.

[3] Amir, H. (2011) Sektor Pertanian: Perlu Upaya Akselerasi Pertumbuhan. Jakarta: Nagamedia Pustaka.

[4] Murtiyani, S. et al. (2016) 'Pengelolaan Kepemilikan Umum dan Negara di Indonesia (Pendekatan Mazhab Hamfara)', Share, 5(1), pp. 83-102.

[5] Hanani, N. (2016) 'Development of Food Security In Indonesia', XVI(01), pp. 12-20.

[6] Sadyohutomo, M. (2018) 'The benefits of an agrarian reform model in Indonesia', in IOP Conference Series: Earth and Environmental Science PAPER, p. 11. doi: doi :10.1088/1755-1315/202/1/012030. 
[7] Marlina, R. et al. (2019) 'Islamic Political Economy: Critical Review of Economic Policy in Indonesia', 1(2), pp. 44-52.

[8] Al-Maliki, A. (2001) Politik Ekonomi Islam. 1st edn. Edited by M. A.- Khattath. Bangil Jawa Timur.

[9] Sihombing, B. F. (2017) 'Agrarian Reform in Indonesia : A Juridical Review’, 8(11), pp. $348-356$.

[10] Condro, D. (2014) Ekonomi Islam Madzhab Hamfara, Falsafah Ekonomi Islam. 1st edn. Jogyakarta: Irtikaz.

[11] An-Nabhani, T. (2010) Membangun Sistem Ekonomi Alternatif (Perspektif Islam). 1st edn. Bogor: Penerbit Risalah Gusti.

[12] Baghdady, A. A.- (1987) Serial Hukum Islam : Penyewaan Tanah Lahan, Kekayaan Gelap, Ukuran Panjang, Luas, Takaran Dan Timbangan. 1st edn. Edited by M. Thohir. Bandung: Penerbit Al Ma`arif.

[13] Yusanto, M. I. (2009) Pengantar Ekonomi Islam. 1st edn. Edited by Arief B. Iskandar. Bogor. 